\title{
Cross-country comparison of engagement in apprenticeships: A conceptual analysis of incentives for individuals and firms
}

\author{
Maia Chankseliani* and Aizuddin Mohamed Anuar \\ University of Oxford, Department of Education 15 Norham Gardens, Oxford, OX2 6PY, UK
}

Received: 24.09.2018, Accepted: 17.07.2019, Published: 19.12.2019

\begin{abstract}
Purpose: A fundamental assumption of the apprenticeship model is that there are benefits to both employers and individual learners. This study offers a broad conceptual interrogation of this inherent assumption underpinning the apprenticeship model.

Approach: This study combines analysis of literature and available data and draws upon apprenticeship systems and practices in ten nations: Australia, Brazil, Denmark, Egypt, England, Finland, Germany, India, Malaysia and South Africa.

Results: For individuals, incentives to undertake apprenticeship may be linked to the process and outcomes of learning, such as the appeal of learning through doing; the opportunities for occupational socialization; the possibility of progression to employment or to additional education; and learning while earning. The analysis of incentives for employers shows a range of reasons related to their short-term interests and the needs of the production processes, technologies, and associated skills; longer-term benefits for the company's staffing strategy; and the opportunity to make a contribution to the wider education and economic systems. Despite all the potential incentives, many firms consider apprenticeships too costly, risky, and complex to justify the investment. However, firms that are making decisions as part of an umbrella associations are more likely to coordinate their skills investment strategies around collectively beneficial outcomes.
\end{abstract}

${ }^{\star}$ Corresponding author: maia.chankseliani@education.ox.ac.uk 
Conclusions: The links to the labour market and specifically to employers are a key challenge for sustaining apprenticeship systems, as well as for the task of researching them. As such, policy maker (and researcher) consideration of apprenticeship should take account of the capacity and commitment of employers. Another key challenge for apprenticeship is related to the relative attractiveness of this pathway for individuals. What is clear from this study is that the development of a strong apprenticeship system requires the buy-in of both employers and individual learners, and as such the necessity to identify and implement incentives effectively cannot be underestimated. Governments can play a key role in realizing the potential incentives for both employers and learners, thereby yielding benefits for all parties engaged in apprenticeships.

Keywords: Apprenticeship, incentives, vocational education, employers, skills, vocational education and training, VET

\section{Introduction}

Apprenticeship is a work-based model of learning that combines on-the-job training in the industry with off-the-job training normally based in vocational institutions. Effective links between productive work and hands-on learning under the supervision of trainers, together with the knowledge acquired in more formal settings, is central to the success of this model of learning. Apprenticeships are valuable in supporting young people's transition from school to work, evident by lower youth numbers not in education, employment or training (NEET) in countries with extensive and well-functioning apprenticeship systems (Biavaschi et al., 2012; European Commission, 2013; Gessler, 2019; Jørgensen, 2017; Valiente \& Scandurra, 2017).

Empirical and theoretical literature on apprenticeships exists at the macro level (e.g. governance and financing, policy-making), meso level (institutional arrangements), and micro level (learning approaches, individual decision-making), either exploring the context of individual countries or examining crosscutting issues from a comparative perspective. Review of the existing literature points to great contextual diversity in the way apprenticeships are financed and organised, the associated institutional arrangements, as well as the approaches to learning. Across different countries, there are variations in the quality of apprenticeship provision as well as the proportion of learners pursuing apprenticeships based on the occupational sector, type of employer and level of apprenticeship. Through a combination of literature and data analysis, supplemented by country-level examples, this article builds on and expands an earlier study (Chankseliani, Keep, \& Wilde, 2017) to offer a broad conceptual interrogation of an inherent assumption in the apprenticeship model, in that it provides incentives for participation to both individual learners and employers. The apprenticeship 
models in ten nations are drawn upon for this study: Australia, Brazil, Denmark, Egypt, England, Finland, Germany, India, Malaysia and South Africa.

Given the aforementioned diversity in apprenticeship arrangements and characteristics, defining apprenticeship in relation to vocational education and training (VET) routes can be complicated. This study subscribes to the following definition that is based on the definition from Chankseliani et al. (2017):

Apprenticeship is a model of learning for an agreed duration that formally combines work-based training (periods of practical work experience at a workplace) with institution-based education (periods of theoretical/practical education followed in a school, college, or training centre), online or face-to-face, and that is regulated by a contract/agreement between apprentice and their employer, provides remuneration for the apprentice, and leads to a nationally recognized qualification/certificate upon successful completion.

Meanwhile, the concept of incentives adopted in this study refers to the factors that motivate individuals to participate in apprenticeships as well as for firms to provide the required volume and quality of training. The concept of incentives as overviewed and discussed in this study is closely linked with the concept of attractiveness. Hence, the study examines what makes apprenticeships attractive to learners and to employers. This is a pertinent question considering that apprenticeship as a mode of learning has been 'increasingly in dispute', arguably 'becoming an ... anachronistic institution' (Young, 1995, p. 137) to the extent that a recent comparative report recognises it as a 'relatively fragile mode of VET' (Chankseliani et al., 2017, p. 85). The article starts by explaining the methodological choices underpinning this study. What follows is an overview of apprenticeship participation in ten national contexts; the statistics reflect between-country differences in supply and demand for this mode of learning. Subsequently, we focus on the conceptualization and analysis of incentives for engaging with apprenticeship for individuals and employers. Finally, the article discusses possible measures that governments can use to enhance some of these incentives.

\section{About the study: methods and sources}

This cross-country comparative study of engagement in apprenticeships utilised documentary analysis as its central methodological approach. Maximum variation sampling was employed to capture commonalities and diversities of apprenticeship provision in ten countries, thereby enabling rich comparison and contrast: Australia, Brazil, Denmark, Egypt, England, Finland, Germany, India, Malaysia and South Africa. These countries were selected to represent a broad range of geographic locations, population sizes, economic characteristics, types 
of apprenticeship provision, apprenticeship participation rates, and degrees of apprenticeship attractiveness.

This study used examples of apprenticeship systems and practices from ten countries. Unlike a traditional empirical case study design, with each country case analysed separately, culminating in a cross-case analysis, this study goes in-depth into the analysis of one important aspect of the ten apprenticeship systems and practices - the logic behind incentives to engage in apprenticeships. This is a conceptual analysis, building on the knowledge from various international contexts

Government websites in the ten countries were carefully examined, focusing on the ministries of education, higher education, labour and economic development, as these were deemed most likely to contain the relevant data, policy documents and descriptions of apprenticeship provision. Individual and multi-country reports were also identified and sourced from the websites of international organizations such as the Organisation for Economic Cooperation and Development (OECD), UNESCO, World Bank, CEDEFOP, IDB, and the ILO.

This study also included academic literature searches using the ERIC and SCOPUS databases; the former captures publications in the field of education internationally while the latter also covers more diverse publications across the fields of science, technology, medicine, social sciences, and arts and humanities. Two search items were entered - the country name and the word 'apprenticeship'. The results were filtered according to criteria agreed in early research team discussions: only peer-reviewed papers, publications with specific reference to apprenticeship, normally dating back no further than twenty years to represent current provision, and predominantly publications in English.

The analysis included the development of brief notes to provide overviews of apprenticeship within each of the ten country contexts. Themes emerged gradually throughout the process of reading, summarising, and collating the secondary material and writing up multiple drafts of this study. The revision of the drafts accounted for new material or issues based on evidence from a particular country. Subsequently, cross-country comparison was undertaken using this emergent thematic structure.

\section{Context: Apprenticeship participation in ten countries}

Incentives for employers and learners to participate in apprenticeships determine the supply of and the demand for apprenticeship within a national context. Although creating a macro indicator for a bundle of incentives operating in each country seems to be impossible, there is one measure that gives an idea about the supply-demand balance and the effectiveness of incentives underlying this balance. This measure is apprenticeship participation that can be expressed as a proportion of the labour force - the sum of employed and unemployed individuals aged 15 to 64 (ILO, 2016) - who participate in apprenticeships in a given country. The 
combination and subsequent calculation of data from national and international databases and from smaller, country-specific reports indicate that the ten countries analysed differ considerably in terms of apprenticeship participation (Fig. 1). The participation in apprenticeship per 1000 in the labour force ranges from 48 in Denmark, to one in Egypt and India. Meanwhile, Germany and England have 33 and 32 apprentices per 1000 in labour force respectively, while Australia has 23 and Finland has 19. There are eight apprentices per 1000 in the labour force in Malaysia, five in South Africa, and two in Brazil.

Fig.1. Number of apprentices per 1000 in labour force

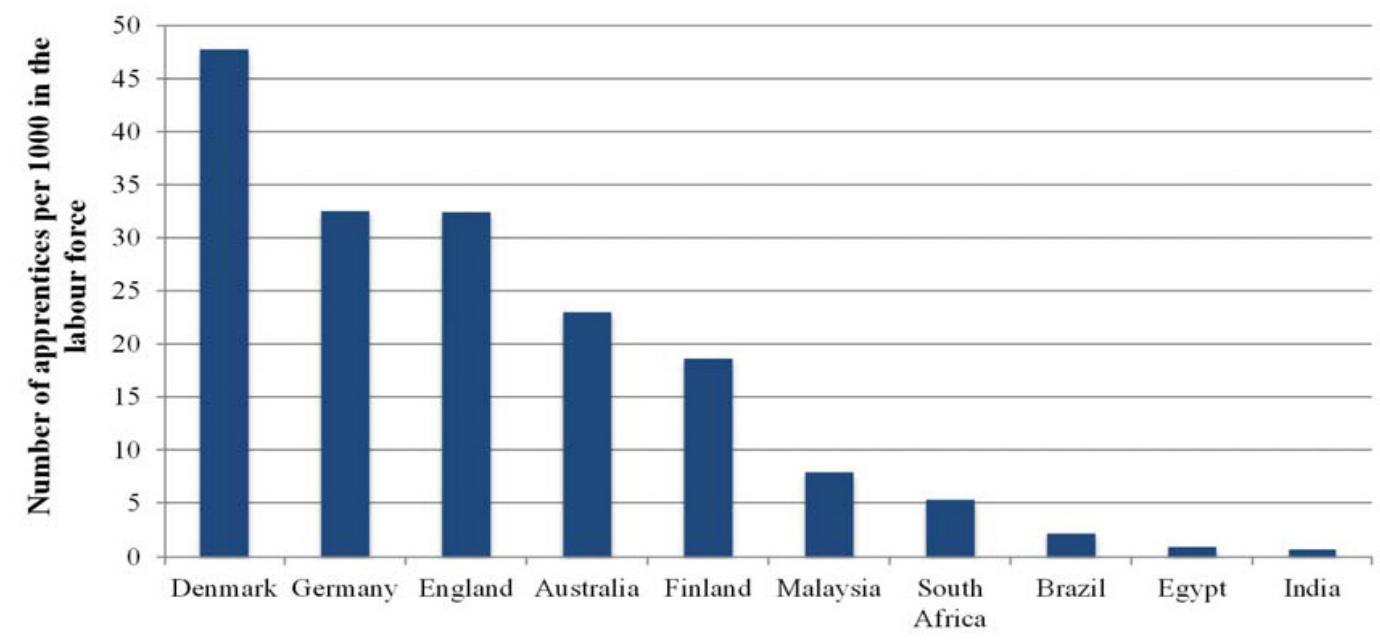

Sources: Own calculations based on the data from Department of Higher Education \& Training (2016); Department of Information Malaysia (2015); Destatis (2015); European Commission (2013); Fazio et al. (2016); Finnish National Board of Education (2016); House of Commons (2016); Ministry of Education of Egypt (2014); NATS (2017); NCVER (2016a); ILO (2017); ONS (2015); Hudson Institute (2017).

Note: The South African numbers are for learnerships (including apprenticeships), but not for internships or other skills programmes. The Australian numbers include apprenticeships and trainFeeships. The Malaysian numbers only cover the National Dual Training System (NDTS).

However, the analysis of participation rates in Fig. 1 is partially compromised by a number of factors. Inherent challenges complicate the handling of apprenticeship data internationally, partly due to the diverse interpretation of the terminologies used in different countries, and the ensuing allocation of categories. For example, in Germany, apprenticeships are generally for young people entering the labour market, whereas in England and Australia, apprenticeship is increasingly becoming an 'all age' provision. In addition, these statistics do not capture 
the substantial role played by informal and non-formal apprenticeship (which is the predominant mode of apprenticeship in India, for example) as well as fragmented apprenticeship schemes that are not aggregated nationally, due to the lack of published and reliable data. A further complication arising in the comparison of apprenticeship participation globally is the data collection method used in international databases (such as UNESCO Institute of Statistics, World Bank, OECD), which do not distinguish between vocational education and training in general, and apprenticeships specifically. Thus, the embeddedness of apprenticeship within each national context necessitates detailed contextualisation of the analysis of incentives and interpretation of the statistics in order to render them meaningful for comparison.

\section{$4 \quad$ Incentives for individuals to engage with apprenticeships}

For individuals, incentives to undertake apprenticeship may be linked to the process of learning as well as the outcomes of that learning. Two aspects of the process and outcomes of learning, respectively, are explored below.

\subsection{The appeal of learning through doing}

The opportunity of learning through doing as a way of exploring the world of work and achieving occupational aspirations can serve as a major incentive for prospective apprentices. The value of the apprenticeship model lies in the technical, cognitive and motivational aspects associated with its integration of theory and practice. In some apprenticeships that practice can result in the development of a craft. In The Craftsman Richard Sennett (2008) explains how skills, judgement, practice and thinking are required to connect hands and head, hence developing craftsmanship. Development of skills starts as a bodily practice, through touch and movement, but it is through the powers of imagination that craftspeople gain technical understanding and forge the connections between hands and head.

Apprenticeship allows the blending of cognitive understanding and practical experience which cannot be achieved through verbal communication alone (Ünlühisarcikli, 2001). It is an action-oriented learning process in workplace settings where apprentices take part in problem solving (Pilz, 2007). Apprentices use real tools in an authentic work environment and their learning is focused on real-life application (Gessler, 2019). Evidently, where learning requires doing, vocational training is more effective in an occupational environment, instead of a school environment: 'Being told in a school how concrete is mixed and poured on a construction site is something quite different from living through the drama and the crises of fifteen or twenty-four hours of continuous, minutely timed and tightly coordinated hard physical work' (Streeck, 1989). Apprenticeship may also be appealing because of the flexible, learner-centred approach to training. As part of the apprenticeship contract in Finland, for 
instance, each apprentice has a personal study plan which is put together by the training organiser and includes the credits for prior training; it also outlines how the apprentice will learn to achieve the desired qualification.

Learning through doing and work-based learning could, however, also become a disincentive if the quality of the learning is not sufficiently high, or if it is very 'restrictive', as defined by Fuller and Unwin (2003 \& 2011). Restrictive learning is characterised by narrow learning objectives and work that is structured around tightly defined tasks, which limits an apprentice's participation in the wider community of practice and constrains the opportunities for developing their identity (Fuller \& Unwin, 2003). The traditional apprenticeships in Egypt demonstrate such a disincentive, where apprentices are perceived as cheap labour and the system is characterised by 'the partial transfer of knowledge from the master to the apprentice; large variations in the quality of the training provided; the perpetuation of existing low-productivity technologies; and a tendency for slow innovation' (Ministry of Education of Egypt, 2014). Learning in this apprenticeship system is commonly passive and non-experimental. Thus, the realities on the ground may not be supportive of the craftsmanship aspirations of apprentices and may discourage others from engaging in this model of learning.

\subsection{Occupational and/or workplace socialization}

Apprentices may also be incentivized by the opportunity for occupational socialization, characterized by the development of 'occupational values and skills which might generalize across organizational settings in which the occupation may be practiced' (Fisher 1986). Occupations ascribed to apprentices reflect the chosen trade, such as baker, hairdresser, plumber, or engineer, and the corresponding socialization may involve the advancement of occupational values such as 'reliability, the ability to hold up under pressure, and solidarity with others working at the same tasks' (Streeck, 1989). Experiencing the reality of a working context is a central feature and appeal of apprenticeships, as indicated in the work of Michaela Brockmann (2013), who conducted studies with retail apprentices in Germany. Apprenticeships in Germany are closely linked to the concept of occupations (Berufskonzept), and are seen as a beneficial mode of learning-acknowledged by individuals and their families-that develops Handlungskompetenz, or competence to act responsibly at the workplace and in society (Brockmann, 2013).

Depending on the sector, the employer and the country context, apprentices may undergo workplace socialization rather than full occupational socialization. In Australia, the concept of socialization seems to be workplace related as the training arrangements refer to the bundles of competencies and skills required for a particular type of work, rather than to individual occupations per se (Pfeifer, 2016). Similarly, in Malaysia's National Dual Training System (NDTS), which was developed through a strategic partnership with Germany star- 
ting in 1996, workplace socialization features through the integration of a broad category of employability skills and social values into the curriculum, thus distinguishing this model from other vocational training schemes in the country (Yahaya, Rasul, \& Yasin, 2016).

Nevertheless, occupational socialization may vary by occupation and by context, resulting in some apprenticeships being more attractive than others. If apprentices are not in an occupation of their choice, perhaps due to high levels of competition or relatively low levels of prior attainment, the value of occupational socialization will be compromised. Furthermore, in countries such as Egypt, India and South Africa, where apprenticeships are often informal and of relatively low status, occupational socialization may not be a viable incentive. In addition, where there is a strong non-formal occupational context, such as in India, these incentives may still accrue without the need to undertake a formal apprenticeship.

\subsection{The possibility of progression to employment or additional education}

Progressions to additional education and training and to decent employment ${ }^{1}$ are also potential incentives for individuals to opt for apprenticeship. Nevertheless, such incentives take different forms in the individual country contexts, based on how apprenticeship is conceived, its worth within the education and training provision and also the labour market structure of each country.

For countries with a high proportion of youth who are NEETs, apprenticeship provision is often touted as a means of increasing youth employability. Brazil's institutionalisation of the Apprenticeship Law in 2000 is one such example, aimed to address the dearth of skills among young people, high employment turnover, and prevalence of informality in the job market (Fazio et al., 2016). An econometric evaluation of the programme under this law revealed it has been successful in increasing real wages and, though employability was slightly lower in the short term, the probability of gaining employment in non-temporary jobs within the formal sector was higher in the medium term (Corseuil, Foguel, Gonzaga, \& Ribeiro, 2014). In the contexts where the likelihood of successful employment is not high, the appeal of apprenticeship, as a consequence, may be relatively limited. Progression from apprenticeship in Egypt is affected by the negative perception towards VET in general and the high societal demand for university education. Further exacerbating this issue is the criticism levied towards the Kohl-Mubarak-Initiative, which has approximately 10,000 entrants annually, as a high proportion of its students then proceed to higher education, hence undermining the programme as a genuine apprenticeship route (Adams, 2010). In South Africa, apprentice-

1 Decent work 'respects the fundamental rights of the human person as well as the rights of workers in terms of conditions of work safety and remuneration. It also provides an income allowing workers to support themselves and their families. [...] ... respect[s] the physical and mental integrity of the worker in the exercise of his/her employment' (UN Economic and Social Council, 2005). 
ships are viewed as a 'bridge' into a world of formal employment, although the opportunities of obtaining such employment are not abundant (Allais, 2012).

In some countries such as Denmark and Germany, apprenticeship ordinarily results in entry into decent and stable employment, though it is unlikely to lead to higher education. Though Denmark has high employment rates for apprenticeship completers, these individuals are not eligible to move into higher education. Such strict separation of academic and vocational routes acts as a disincentive for some individuals (Jørgensen, 2017). Meanwhile, in Germany, the traditional model of vocational/academic separation has been dissolving in recent years. Access to higher education has been extended to 'non traditional' students with vocational qualifications instead of the Abitur school-leaving certificate, although the reach is limited: data from 2013 indicates that three percent of first-year students were non-traditional, but their proportion has more than quintupled since 1993 (Wolter \& Kerst, 2015).

Australia, England and Finland demonstrate relatively flexible education and training systems and robust labour markets that ensure transition to employment as well as the possibility to move from vocational to academic routes. In Australia, 92\% of apprenticeship completers in trade occupations and $80 \%$ of those in non-trade occupations gain employment (NCVER, 2016b). The Australian Qualifications Framework (AQF) indicates that the aim of all qualifications (except for the doctorate) includes 'a pathway for further learning' (AQF Council, 2011 ) and the latest data indicates that $23 \%$ of completers progressed to further education (NCVER, 2010). Meanwhile, a longitudinal study in England established that 19\% of advanced apprenticeship (those equivalent to upper secondary level academic learning, i.e. Level 3) completers progressed to higher education over seven years (Smith, Joslin, \& Jameson, 2015). Finnish apprenticeship completers can also continue to universities and polytechnics after completing an upper secondary vocational school qualification (Aho, Pitkanen, \& Sahlberg, 2006; Stenström \& Virolainen, 2014b).

On the other hand, the continuing absence of a well-developed national qualifications framework in India results in the minimal utility of apprenticeship certificates for progression into higher-level qualifications. Apprentices who pass their trade tests obtain a National Apprenticeship Certificate but, without integration into a national qualification framework, such certificates remain outside the formal educational system and are therefore relatively unattractive to potential entrants who are looking for pathways to additional higher qualifications (ILO \& World Bank, 2013). Thus, progression routes to additional education from apprenticeship are a potentially powerful incentive for participants. However, complex patterns of progression outlined here reflect the difficulties of providing an effective progression pathway while balancing the utility of apprenticeship as a direct route to employment. 


\subsection{Learning while earning}

The fact that apprenticeship allows individuals to earn wages while learning can serve as a very strong incentive for participation. However, in some contexts, individuals may earn more by joining the labour market directly rather than by pursuing an apprenticeship. Therefore, higher pay for unskilled labour may discourage an individual from choosing an apprenticeship and having to shoulder a portion of the training costs (through lower pay), compared to joining the labour market directly.

Apprentices in all ten countries receive wages (referred to as wages, pay, stipend in the case of South Africa and India, or allowance in Malaysia). However, there are considerable variations in the wage amount and arrangements within and between countries. In some countries, apprenticeship offers relatively high levels of remuneration, whereas in other countries, for example in Egypt and India, the pay is extremely low, with no guarantee of post-apprenticeship employment (Álvarez-Galván, 2015; ILO \& World Bank, 2013).

Different wage arrangements can provide different incentives for individuals to participate in apprenticeships. In some countries, such as Denmark and Germany, apprentices receive wages for the entire period of their apprenticeship engagement, without any differentiation between their on-the-job training and school-based training (Kuczera, 2017a). In Malaysia, the monthly allowance for apprentices progressively increases over the four semesters in the two-year period (Othman, 2005). In other contexts, financial allowances in addition to wages are offered to apprentices. For example, in Australia apprentices who have moved away from their parents' home receive The Living Away From Home Allowance. Australian apprentices may also receive the allowance if they are undertaking an apprenticeship and are or become homeless (Australian Apprenticeships, 2013). In Finland, apprentices are offered one free meal per day, can receive school transport and accommodation allowances, and are able to access financial support if they have limited means, are mature students or have families to care for while learning (Finnish National Board of Education, 2016).

Three out of the ten countries - Denmark, Finland and Germany - use collective wage agreement systems to decide apprenticeship pay rates, generally resulting in relatively attractive salaries for apprentices. In Finland, for example, the trainees receive wages of about $80 \%$ of the wages of a skilled worker in a particular field (Stenström \& Virolainen, 2014a). Contrast this with England, where relatively few private sector employees are covered by any kind of collectively bargained wage agreement; employers have the liberty to set apprenticeship wage rates at their own discretion. A national minimum rate for apprentices below the age of 19 is in place, coupled with a requirement that the apprenticeship wages meet the minimum standard set by the National Minimum Wage. However, this requirement is not always adhered to (BEIS, 2017). Meanwhile in Brazil, apprentices must be paid at least the rate of the national minimum wage, regardless of age, though there are restrictions on the number of working 
hours depending on whether or not the individual has completed compulsory education (OECD, 2014).

The examination of apprentice pay reveals its complexity, enmeshed as it is within the wider economic systems and institutional arrangements. Potential determinants of apprentice pay may include the organized interests of employers and employees, the mode and content of state intervention, the supply and demand for trainees, as well the presence of a gendered dimension in specific sectors (Ryan, Backes-Gellner, Teuber, \& Wagner, 2013; Williams, Foley, \& Newton, 2013). While apprentice wages may not always be high and therefore appealing across and within selected national contexts, the idea of receiving pay while being trained is in itself very attractive (Heine, Spangenberg, \& Willich, 2007; Lehmann, Taylor, \& Wright, 2014; Williams et al., 2013), especially in contexts where apprenticeship completers are highly likely to be employable. This is a cornerstone of apprenticeship provision and one of the key incentives for individuals.

\section{Incentives for employers to engage with apprenticeship}

Employer engagement is an essential component of apprenticeships; firms' willingness to train apprentices is the conditio sine qua non for an apprenticeship system (Wolter \& Ryan, 2011). Employers, as atomistic entities, may view skills as a private, firm-specific good, or may conceive themselves as part of collective entities and see skills as both a private and collective good. These two assumptions underpin the analysis that follows. The aforementioned occupational socialization benefits employers through the opportunity to develop employees within the specific work settings where such skills will be deployed, as well as to expose new employees to the firm's work routine. Furthermore, employers potentially benefit from apprentices' contribution towards productivity following their initial training period. In Germany, $41 \%$ of employers participating in a nationally-representative survey selected 'to employ apprentices as workers even during apprenticeship training' as a reason for providing in-company vocational training (BIBB, 2015). Additionally, in Denmark, there is positive employer feedback on the contribution made specifically by adult apprentices who are perceived to be highly motivated trainees (European Commission, 2014).

The opportunity to undertake preliminary observation of apprentices on the job and to expose them to training as a pre-condition for permanent employment can also be considered an incentive for employers (Jansen, Leiser, Wenzelmann, \& Wolter, 2015). In Germany, $83 \%$ of employers participating in a nationally-representative survey rated 'to train young workers with a view to employing them long-term in the company as skilled workers' as a reason for providing in-company vocational training (BIBB, 2015). Employers also benefit from the fact that following their initial period of training, apprentices contribute to productivity. In Germany, an increase of the share of apprentices in a firms' workforce in trade, 
commercial, craft or construction occupations is linked with higher labor productivity and profitability (Mohrenweiser \& Zwick, 2009). The training costs borne by the companies are generally low when considering the productivity of the apprentice across the training period. In England, research suggests that most employers were able to recoup the costs of their investment in apprenticeship training within one to two years (Hasluck \& Hogarth, 2010).

The benefits of apprenticeship arrangements are linked to apprenticeship costs and funding arrangements. The main costs of providing apprenticeship are apprentice wages, training in schools and off-the-job settings, and assessment costs. Depending on the country context, various cost sharing permutations exists between firms (through direct payment and levies), governments and apprentices. In Finland's publicly funded apprenticeship system, the employer receives training compensation to cover the costs of workplace training, whereby employers taking on an apprentice directly from basic education receive an increased subsidy (OPH, 2016). Incentive payments are also available in Australia for employers who take apprentices in occupations that are on the National Skills Needs List (ILO, 2018). The South African case, however, demonstrates how some cost sharing arrangements can create disincentives for employers. The assessment of the South African levy shows that '[a] problem has been the continuation of a "voluntarist" and "short-term" mind-set towards enterprise training among employers. Many employers [...] view [levy] as little more than an additional tax burden impacting negatively on cost structure and profit margins' (Kraak, 2008).

Irrespective of the funding arrangement model, firms' investment in apprentice training can support the apprentice-employer relationship, potentially leading to greater motivation and company loyalty (Poulsen \& Eberhardt, 2016), as apprentices appreciate their employer's willingness to play an active role in their development by investing in training. Firms offering apprenticeships can also gain a reputational benefit by honouring the tradition of investing in people. In Germany, when probed on the reason for providing in-company vocational training, $41 \%$ of participating employers in a nationally-representative survey responded: 'because apprenticeship is part of tradition' (BIBB, 2015). In other words, firms are encouraged to participate in apprenticeships in order to adhere to a set of societal expectations and values tied to the development of human resources in that society.

Despite all the factors that may incentivize employers to offer apprenticeships, many firms view apprenticeship arrangements as too costly, risky and complex to justify the investment. One of the main disincentives is that trained apprentices may leave their employer following the completion of training when attracted by a competing firm, a phenomenon referred to as poaching or free-riding. In this case, the likelihood that firms are unable to justify investments in apprenticeship training is high. Consequently, save for a few exceptions in stronger systems like Germany and Denmark, employers expect the broader education and training system - funded by individuals or the taxpayers - to produce appropriately trained talent which they can source using competitive pay strategies. 
In addition, the relatively low status of apprenticeship in some countries also affects the willingness of employers to partake in this model. In India, where on-the-job training in family businesses or informal employment is particularly important in economic areas such as street food vending, the need for recognized and certified skills may be less urgent. This is due to the high employment levels for those with informally acquired skills, the high cost associated with formal training and the prominent role of families in transferring knowledge and skills in traditional sectors (Noronha \& Endow, 2011; Pilz, Uma, \& Venkatram, 2015). As a result, the disincentives for apprenticeships in India are reflected by this rather blunt assessment: 'Young people do not tend to see apprenticeship as a valued career path, and employers have been reluctant to employ apprentices' (OECD \& ILO, 2017).

Thus, a strong and stable apprenticeship system with a '...high degree of standardization and consistency' as exemplified in Germany and Denmark can motivate firms to be involved in apprenticeship on a relatively constant basis (Pfeifer, 2016). This contrasts with the 'fractured' system in England (Keep, 2015), the 'relatively dynamic policy-driven development' in Australia (Pfeifer, 2016), Malaysia's system that is largely propped up by the government with the industry only playing a supporting role (Pang, Rajamorganan, \& Sim, 2010), and the struggle to establish a functioning system in countries such as Egypt, India and South Africa.

\subsection{The value of collective efforts}

In contrast to the many microeconomic disincentives briefly described above, below we present institutional explanations of firms' incentives. Institutional explanations encompass country-specific collective institutions, such as: employer collective organizations (associations, chambers of commerce/trade), employee organizations (unions, councils), associations of educational vocational centres/schools/colleges, as well as trainee/learner associations. Specifically, we focus on employer collective organizations as key social partners. One assumption in previously reviewed incentives and disincentives for apprenticeships was that skills are a private, firm-specific good. Here, the assumption shifts to consider skills as a broader, collective good instead.

When firms make decisions collectively, under the umbrella of chambers or associations, they are more likely to coordinate their skills investment strategies around mutually-beneficial outcomes linked to skills development as a common good, locally or nationally. From the employer's perspective, Streeck (1989) highlights that 'if an employer provides training, he is no more than adding to a common pool of skilled labour which is in principle accessible to all other employers in the industry or the locality, many of which are his competitors' (p. 94). Therefore, as a collective, the investment and effort of training apprentices are then viewed as a contribution to the 'pool' of talent for the broader sector rather than limited to individual firms. Employers engaging in apprenticeship provision as part of collectives may be more 
inclined to provide apprenticeships than individual firms. Such collectively-owned organisations may be more legitimate bodies to design, assess and administer apprenticeships than public officials. As a collective, firms may be more receptive to share the information about their skill needs and training options amongst themselves rather than with the government (Culpepper, 2003; Wolter \& Ryan, 2011). This sense of collective ownership may also prompt employer associations/chambers to use different mechanisms, such as 'dialogic capacity' or peer pressure (Wolter \& Ryan, 2011) to persuade resistant firms to invest in the development of mutually beneficial human resource.

Collective employer structures usually exist in countries that have had a long history of apprenticeship training, such as Germany and Denmark. The non-optional employer body - the Association of German Chambers of Commerce and Industry (DIHK) - offers support and advice for individuals with questions regarding apprenticeship training. They provide mediation for problems, determine the suitability of businesses and trainers, register the training contracts, administer examinations and issue certificates (DIHK, 2017). The Employers' Reimbursement Fund (AUB) in Denmark is an example of a collective structure that establishes a common fund that spreads out the cost and benefits of apprenticeship training amongst its members. All employers in Denmark make contributions to this fund for each full-time employee; subsequently employers with apprentices can then claim reimbursement when their trainees attend a vocational school.

Halfway through the spectrum, South Africa and Australia present examples of employer collective bodies that are not as extensive as those in Germany or Denmark. For example, in South Africa, the Tripartite Sector Education and Training Authorities (SETAs) implement sector skills plans by starting learnerships, disbursing the training levies contributed by all employers, approving workplace skills plans from employers, and overseeing education and training in their sectors. SETAs include representatives from trade unions, employers' associations, the government, and professional bodies (Department of Labour, 2014). In Australia, the Industry Skills Councils are government-recognized and funded bodies representing employers in different sectors that participate in developing the skills and productivity of the sector's workforce.

By contrast, in Egypt, employers' involvement through collective organizations is limited, except for the MKI dual-system programme where investors' associations of mostly medium and large companies provide the practical training component of the programme. When apprentices finish the training, they receive a certificate from the association and a diploma from the Ministry of Education (Ministry of Education of Egypt, 2014). Meanwhile, Pang, Rajamorganan, and Sim (2010) observed that in the case of Malaysia, employers are not able to take on the role of administering apprenticeship contracts and assessments, or even promoting apprenticeships; these functions are mainly driven by the government's Department of Skills Development. Overall, the analysis aligns with Wolter \& Ryan's (2011) argument 
that countries without organically developed institutions for employer coordination and/or social partnership may face an uphill task in expanding apprenticeship provision. Collective mechanisms as exemplified above may potentially incentivize employers to view apprentice training as a sector-wide investment, though such institutional structures are historically determined within each country context, and are extremely difficult to construct from scratch.

\section{How can governments enhance some of these incentives?}

There is an indication in literature that governments have tried, with various success, introducing incentives for engagement in apprenticeships (Hargreaves, Stanwick, \& Skujins, 2017). Despite the complexity of the nature of such incentives, governments are in a position to encourage employers as well as learners to engage with apprenticeship. A number of these possible measures are discussed below.

The attractiveness of apprenticeship among young people can be increased by improving schools-based education and training provision, focusing on enhancing VET teacher training, informing parents, career professionals and teachers as key influencers for young people (Loveder, 2017), providing the flexibility for individuals to move from one qualification to another within the vocational route as well as into the academic pathway. Governments can also tap into the potential of events such as WorldSkills competitions to encourage people to pursue this route (Chankseliani, James Relly, \& Laczik, 2016; Chankseliani, James Relly, \& Mayhew, 2015). WorldSkills competitions currently feature 77 member organizations and countries, including those included in this study. The broad aims of these competitions, which have been taking place biannually since 1950, are to promote greater awareness of the contribution of skills and high standards of competence towards individual fulfilment and also economic success.

Employers may be incentivized to offer apprenticeships when the government provides optimal sets of financial and non-financial incentives to balance employer costs and benefits. This entails supporting the training of in-company trainers, contributing to apprentice wages, or offering particular tax incentives. In most EU countries the national government offers support for training programmes aimed at in-company trainers who are responsible for delivering the on-the-job elements of apprenticeship, and in some jurisdictions having appropriately trained trainers is a prerequisite before firms are allowed to take on apprentices. Simplification of bureaucracy and regulation may also facilitate employers' engagement with apprenticeships, especially when the system is government-led. The introduction of branding schemes that recognize and endorse firms as 'learning enterprises'- exemplified by the Norwegian government through its PR campaign - may also serve as a non-financial incentive. Such recognition may indirectly influence firms' profit, as socially responsible companies are more likely to sell their products and services (CEDEFOP, 2016; Kuczera, 2017b). Govern- 
ments can also 'promote and build the brand confidence of apprenticeships' (APPG, 2017), through effective communication with firms on the benefits and latest policy developments associated with apprenticeships. Equally important is government engagement with individuals to communicate the benefits of participating in apprenticeships, especially to those who are currently under-represented in terms of age, gender, ethnicity groups and geographical areas. Governments are also well positioned to facilitate communication between employers, VET institutions and individuals, for instance by orchestrating a public information exchange 'marketplace' involving the use of apps and websites. In such a marketplace, employers offering apprentice spots, institutions offering formal training, and individuals seeking training can come together to realize the potential of apprenticeships jointly.

\section{$7 \quad$ Concluding remarks}

Apprenticeship is a model of learning that integrates practice and theory, providing cognitive and motivational benefits, facilitating the alignment of the content of educational and training programmes with the occupational requirements, and resulting in enhanced opportunities for individual employment as well as better skills match across the national economy. Despite a growing political interest in apprenticeship globally, it remains a relatively fragile mode of vocational education (Chankseliani et al., 2017); this is largely because of its reliance on employer engagement and its low attractiveness to individuals in many different parts of the world. It was therefore important to explore what potential incentives are present for employers and individuals to engage with apprenticeship. This study explained the logic of incentives to participate in apprenticeship for both employers and individual learners using the data and literature from ten national contexts to show that individuals may be attracted to apprenticeships because of the appeal of learning through doing; the opportunities for occupational socialization; the possibility of progression to employment or to additional education; and the lure of learning while earning. Employers' interest in offering apprenticeships are normally linked to their short-term needs of the production processes, technologies, and associated skills; longer-term benefits for the company's staffing strategy; and the opportunity to make a contribution to the wider education and economic systems. When firms coordinate their skills investment strategies as part of their sectoral associations, they are more likely to invest in apprenticeships. However, such institutional arrangements are not in place in most international contexts and employer engagement remains a key challenge for sustaining apprenticeship systems. In many countries, apprenticeship is yet another government training scheme without taking account of the capacity and commitment of employers.

The low attractiveness of apprenticeship, to employers and to individuals, may be linked to the unclear purpose of apprenticeship in some countries. Apprenticeship is commonly seen as 'the answer' to a wide range of policy issues related to unemployment, skills shortages 
and skills mismatch, social exclusion and economic problems. Hence, there exists a tension between wanting apprenticeship to be viewed as a rigorous, high status model of learning and also wanting to use it as a mechanism for providing second chance, social inclusion goals for young people who have not succeeded on the academic route of the mainstream schooling. Focusing on apprenticeship as a worthwhile route in its own right unlocks the true potential of enhancing the incentives and making apprenticeship genuinely attractive to learners and employers. What is clear from this study is that the development of a strong apprenticeship system requires the buy-in of both employers and individual learners, and the importance of identifying and implementing incentives effectively cannot be underestimated. Governments can play a key role in realizing the potential incentives for both employers and learners, thereby yielding benefits for all parties engaged in apprenticeships.

\section{References}

Adams, A. V. (2010). The Mubarak Kohl initiative - Dual system in Egypt: An assessment of its impact on the school to work transition. Retrieved from http://epp-egypt.net/uploads/resources/2012-10_ Assessment_of_DS_in_Egypt_en.pdf

Aho, E., Pitkanen, K., \& Sahlberg, P. (2006). Policy development and reform principles of basic and secondary education in Finland since 1968. Washington, D.C.: The World Bank. Retrieved from http://documents.worldbank.org/curated/en/124381468038093074/pdf/368710FI0Educales0Ma y0200601PUBLIC1.pdf

Allais, S. (2012). Will skills save us? Rethinking the relationships between vocational education, skills development policies, and social policy in South Africa. International Journal of Educational Development, 32(5), 632-642. https://doi.org/10.1016/j.ijedudev.2012.01.001

Álvarez-Galván, J.-L. (2015). A skills beyond school review of Egypt. OECD reviews of vocational education and training. Paris, France: OECD Publishing. https://doi.org/10.1787/9789264209626-en

APPG (All-Party Parliamentary Group on Apprenticeships).(2017). Annual report 2016-2017. Retrieved from https://connectpa.co.uk/wp-content/uploads/2017/07/2017-Annual-Report-APPGApprenticeships-low-res.pdf

AQF Council. (2011). Australian Qualifications Framework. Retrieved from https://www.aqf.edu.au/ sites/aqf/files/aqf-1st-edition-july-2011.pdf

Australian Apprenticeships. (2013). Incentives. Retrieved July 2, 2017, from https://www.australianapprenticeships.gov.au/programs/incentives

BEIS (Department for Business, Energy \& Industrial Strategy).(2017). Apprenticeship pay survey 2016: England. BEIS Research Paper No. 15. Retrieved from https://www.gov.uk/government/ uploads/system/uploads/attachment_data/file/630082/apprenticeship-pay-survey-2016-reportengland.pdf

Biavaschi, C., Eichhorst, W., Giulietti, C., Kendzia, M., Muravyev, A., Pieters, J., \& Zimmermann, K. (2012). Youth unemployment and vocational training. Bonn, Germany: The Institute for the Study of Labor (IZA). Retrieved from http://ftp.iza.org/dp6890.pdf 
BIBB (Bundesinstitut für Berufsbildung).(2015). Apprenticeship training in Germany remains investment-focused - results of BIBB Cost-Benefit Survey 2012/13. BIBB Report 1/2015. Retrieved from https://www.bibb.de/en/25852.php

Brockmann, M. (2013). Learning cultures in retail: Apprenticeship, identity and emotional work in England and Germany. Journal of Education and Work, 26(4), 357-375. https://doi.org/10.1080/1 3639080.2012.661847

CEDEFOP (European Centre for the Development of Vocational Training).(2016). Norway: A new brand promotes enterprises that take apprentices. Retrieved from http://www.cedefop.europa.eu/ en/news-and-press/news/norway-new-brand-promotes-enterprises-take-apprentices

Chankseliani, M., James Relly, S., \& Laczik, A. (2016). Overcoming vocational prejudice: How can skills competitions improve the attractiveness of vocational education and training in the UK? British Educational Research Journal, 42(4), 582-599. https://doi.org/10.1002/berj.3218

Chankseliani, M., James Relly, S., \& Mayhew, K. (2015). Benefits of developing vocational excellence: A report to the national apprenticeship service of project 3 (Phase II) of the DUVE suite of projects. Retrieved from https://www.worldskillsuk.org/media/2350/project-3-benefits-04112015.pdf

Chankseliani, M., Keep, E., \& Wilde, S. (2017). People and policy: A comparative study of apprenticeship across eight national contexts. World Innovation Summit for Education (WISE). Retrieved from https://www.wise-qatar.org/app/uploads/2019/04/rr.9.2017_oxford.pdf

Corseuil, C. H., Foguel, M., Gonzaga, G., \& Ribeiro, E. P. (2014). Youth turnover in Brazil: Job and worker flows and an evaluation of a youth-targeted training program. La Plata, Argentinia: Universidad Nacional de La Plata. Retrieved from https://ideas.repec.org/p/dls/wpaper/0155.html

Culpepper, P. D. (2003). Creating cooperation: How states develop human capital in Europe. Cornell studies in political economy. Ithaca, NY: Cornell University Press.

Department of Higher Education \& Training. (2016). Statistics on post-school education and training in South Africa: 2014. Retrieved from Department of Higher Education \& Training website: http:// www.justice.gov.za/commissions/FeesHET/docs/2014-Statistics-Post-School-ET-SA.pdf

Department of Information Malaysia. (2015). Mengarusperdana Latihan Kemahiran. Retrieved from http://www.penerangan.gov.my/dmdocuments/mengarusperdana_latihan_kemahiran/files/assets/common/downloads/publication.pdf

Department of Labour. (2014). Basic guide to Sector Education and Training Authorities (SETAs) Retrieved from http://www.labour.gov.za/DOL/legislation/acts/basic-guides/basic-guide-to-sectoreducation-and-training-authorities-setas

Destatis (Statistisches Bundesamt).(2015). Bildung, Forschung und Kultur: Berufliche Bildung. Retrieved from https://www.destatis.de/DE/Themen/Gesellschaft-Umwelt/Bildung-Forschung-Kultur/Berufliche-Bildung/_inhalt.html

DIHK (Deutscher Industrie- und Handelskammertag).(2017). Education and training. Retrieved July 6, 2007, from https://www.dihk.de/en/segments/training/education-training

European Commission (2013). Apprenticeship and traineeship schemes in EU 27: Key Success factors - A guidebook for policy planners and practitioners. Retrieved from European Commission website: ec.europa.eu/social/BlobServlet?docId=11348\&langId=en

European Commission (2014). Mutual learning programme database of national labour market practices. Denmark - Adult apprenticeships. Retrieved from http://ec.europa.eu/social/main.jsp?catId $=1080 \&$ langId $=$ en $\&$ practiceId $=32$ 
Fazio, M. V., Fernández-Coto, R., \& Ripani, L. (2016). Apprenticeships for the XXI Century: A model for Latin America and the Caribbean? Retrieved from Inter-American Development Bank website: http://publications.iadb.org/handle/11319/7855

Finnish National Board of Education. (2016). Key figures on apprenticeship training in Finland. Retrieved from http://www.oph.fi/english/publications/2016/key_figures_on_apprenticeship_training_in_finland

Fisher, C. (1986). Organizational socialization: An integrative review. In K. M. Rowland, \& G. R. Ferris (Eds.), Research in Personnel and Human Resources Management (Vol. 4, pp. 101-145). Greenwich, CT: JAI Press.

Fuller, A., \& Unwin, L. (2003). Learning as apprentices in the contemporary UK workplace: Creating and managing expansive and restrictive participation. Journal of Education and Work, 16(4), 407-426. https://doi.org/10.1080/1363908032000093012

Fuller, A., \& Unwin, L. (2011). Apprenticeship as an evolving model of learning. Journal of Vocational Education \& Training, 63(3), 261-266. https://doi.org/10.1080/13636820.2011.602220

Gessler, M. (2019). Concepts of apprenticeship: Strengths, weaknesses, and pitfalls. In S. McGrath, M. Mulder, J. Papier, \& R. Suart (Eds.), Handbook of vocational education and training (pp. 677-709). Cham, Switzerland: Springer. https://doi.org/10.1007/978-3-319-94532-3_94

Hargreaves, J., Stanwick, J., \& Skujins, P. (2017). The changing nature of apprenticeships: 1996-2016. Retrieved from https://www.ncver.edu.au/_data/assets/pdf_file/0028/367255/The-changing-nature-of-apprenticeships-1996-2016.pdf

Hasluck, C., \& Hogarth, T. (2010). The net benefits to employers' investments in apprenticeships: Case study evidence from the UK. The Canadian Apprenticeship Journal, 2. Retrieved from http://wrap. warwick.ac.uk/34559/

Heine, C., Spangenberg, H., \& Willich, J. (2007). Studienberechtigte 2006 ein halbes Jahr vor Schulabgang: Studierbereitschaft und Bedeutung der Hochschulreife. Retrieved from http://ids.hof.unihalle.de/documents/t1503.pdf

House of Commons. (2016). Apprenticeship statistics: England. Retrieved from http://researchbriefings.files.parliament.uk/documents/SN06113/SN06113.pdf

Hudson Institute. (2017). Modi: Three years on. Retrieved from https://s3.amazonaws.com/media. hudson.org/files/publications/ModiThreeYearsOn.pdf

ILO (International Labour Organization).(2016). Labour force. Definition. Retrieved from http:// www.ilo.org/global/statistics-and-databases/statistics-overview-and-topics/WCMS_470304/lang-en/index.htm

ILO (International Labour Organization).(2017). Labour force by sex and age (Thousands). Retrieved from https://www.ilo.org/ilostat/faces/oracle/webcenter/portalapp/pagehierarchy/Page27. jspx ? subject $=E A P \&$ indicator $=E A P \_T E A P \_S E X \_A G E \_N B \&$ datasetCode $=A \&$ collectionCode $=$ YI\&_afrLoop=359764306723494\&_afrWindowMode=0\&_afrWindowId=e4lglsthj_42\#!\%40\%4 0\%3Findicator\%3DEAP_TEAP_SEX_AGE_NB\%26_afrWindowId\%3De4lglsthj_42\%26subjec t\%3DEAP\%26_afrLoop\%3D359764306723494\%26datasetCode\%3DA\%26collectionCode\%3D YI\%26_afrWindowMode\%3D0\%26_adf.ctrl-state\%3De4lglsthj_107

ILO (International Labour Organization).(2018). ILO Survey Report on the National Initiatives to Promote Quality Apprenticeships in G20 Countries. Retrieved from http://www.ilo.org/employment/Whatwedo/Publications/WCMS_633677/lang--en/index.htm 
ILO (International Labour Organization), \& World Bank. (2013). Possible futures for the Indian apprenticeship system: Options paper for India. Retrieved from http://www.ilo.org/newdelhi/whatwedo/publications/WCMS_234727/lang--en/index.htm

Jansen, A., Leiser, M. S., Wenzelmann, F., \& Wolter, S. C. (2015). Labour market deregulation and apprenticeship training: A comparison of German and Swiss employers. European Journal of Industrial Relations, 21(4), 353-368. https://doi.org/10.1177/0959680115580687

Jørgensen, C. H. (2017). From apprenticeships to higher vocational education in Denmark - building bridges while the gap is widening. Journal of Vocational Education \& Training, 69(1), 64-80. https://doi.org/10.1080/13636820.2016.1275030

Keep, E. (2015). Governance in English VET: On the functioning of a fractured 'system'. Research in Comparative and International Education, 10(4), 464-475.

Kraak, A. (2008). A critical review of the national skills development strategy in south africa. Journal of Vocational Education \& Training, 60(1), 1-18. https://doi.org/10.1080/13636820701828762

Kuczera, M. (2017a). Incentives for apprenticeship. OECD Education Working Papers No. 152. Paris: OECD Publishing. https://doi.org/10.1787/55bb556d-en

Kuczera, M. (2017b). Striking the right balance: Costs and benefits of apprenticeship. OECD Education Working Papers 153. Paris: OECD Publishing. https://doi.org/10.1787/995fff01-en.

Lehmann, W., Taylor, A., \& Wright, L. (2014). Youth apprenticeships in Canada: On their inferior status despite skilled labour shortages. Journal of Vocational Education \& Training, 66(4), 572-589. https://doi.org/10.1080/13636820.2014.958868

Loveder, P. (2017). Australian apprenticeships: Trends, challenges and future opportunities for dealing with Industry 4.0. Retrieved from https://eric.ed.gov/?id=ED578882

Ministry of Education of Egypt. (2014). Egypt country report for the 2014 ministerial conference on youth employment: How to Improve, Trough Skills Development and Job Creation, Access of Africa's Youth to the World of Work. Retrieved from http://www.adeanet.org/min_conf_youth_ skills_employment/sites/default/files/u24/Egypt\%20Country\%20Report_0.pdf

Mohrenweiser, J., \& Zwick, T. (2009). Why do firms train apprentices? The net cost puzzle reconsidered. Labour Economics, 16(6), 631-637. https://doi.org/10.1016/j.labeco.2009.08.004

NATS (National Apprenticeship Training Scheme).(2017). National Apprenticeship Training Scheme (NATS), Ministry of Human Resource Development. Retrieved from http://mhrdnats.gov.in/

NCVER (National Centre for Vocational Education Research).(2010). Australian vocational education and training statistics. Aprpentice and trainee destinations. Retrieved from https://www.ncver.edu. au/_data/assets/file/0023/7529/aats_dest_2010_2262.pdf

NCVER (National Centre for Vocational Education Research).(2016a). Apprentices and trainees 2015: Infographic. Retrieved from https://www.ncver.edu.au/data/data/infographics/apprentices-andtrainees-2015-infographic

NCVER (National Centre for Vocational Education Research).(2016b). Total VET graduate outcomes 2016 summary findings. Retrieved from https://www.ncver.edu.au/data/data/all-data/total-vetgraduate-outcomes-2016-summary-findings

Noronha, C., \& Endow, T. (2011). Informal training for skilled workers: Issues arising from a qualitative study in four sites in Rajasthan and Madhya Pradesh. International Journal of Training Research, 9, 110-122. https://doi.org/10.5172/ijtr.9.1-2.110

OECD (Organisation for Economic Cooperation and Development).(2014). Investing in youth: Brazil. Paris, France: OECD Publishing. https://doi.org/10.1787/9789264208988-en 
OECD (Organisation for Economic Cooperation and Development), \& ILO (International Labour Organization).(2017). Engaging employers in apprenticeship opportunities: Making it happen locally. Paris, France: OECD Publishing. https://doi.org/10.1787/9789264266681-en

ONS (Office for National Statistics).(2015). Employment and labour market. Retrieved from https:// www.ons.gov.uk/file?uri=/employmentandlabourmarket/peopleinwork/employmentandemployeetypes/datasets/labourmarketstatistics/current/lms.csv

OPH (Finish National Agency for Education).(2016). Key figures on apprenticeship training in Finland. Edited by T. Kumpulainen. Tampere: Finish National Board of Education. Retrieved from http://www.oph.fi/english/publications/2016/key_figures_on_apprenticeship_training_in_finland

Othman, A. (2005). The National Dual Training System: An alternative mode of training for producing k-workers in Malaysia? In A. Ahmad (Ed.), Human Resource Development: Practices and Directions for a Developed Malaysia (pp. 3-8). Serdang, Malaysia: Universiti Putra Malaysia Press.

Pang, C. L., Rajamorganan, N., \& Sim, S. (2010). Background paper for Malaysia: Skills development in the workplace in Malaysia. Chiba, Japan: Workplace Overseas Vocational Training Associations.

Pfeifer, H. (2016). Firms' motivation for training apprentices: An Australian-German comparison. Adelaide, Australia: National Centre for Vocational Education Research.

Pilz, M. (2007). Two countries - one system of vocational education? A comparison of the apprenticeship reform in the commercial sector in Switzerland and Germany. Compare: A Journal of Comparative and International Education, 37(1), 69-87. https://doi.org/10.1080/03057920601061802

Pilz, M., Uma, G., \& Venkatram, R. (2015). Skills development in the informal sector in India: The case of street food vendors. International Review of Education, 61(2), 191-209. https://doi.org/10.1007/ s11159-015-9485-X

Poulsen, S. B., \& Eberhardt, C. (2016). Approaching apprenticeship systems from a european perspective. Discussion Paper No. 171. Bonn. Bundesinstitut für Berufsbildung. Retrieved from https://www.bibb.de/veroeffentlichungen/en/publication/show/7987

Ryan, P., Backes-Gellner, U., Teuber, S., \& Wagner, K. (2013). Apprentice pay in Britain, Germany and Switzerland: Institutions, market forces and market power. European Journal of Industrial Relations, 19(3), 201-220. https://doi.org/10.1177/0959680113494155

Sennett, R. (2008). The Craftsman. London, England: Penguin.

Smith, S., Joslin, H., \& Jameson, J. (2015). Progression of apprentices to higher education-2nd cohort update. BIS Research Paper Number 240. London: Department for Business Innovation \& Skills. Retrieved from http://gala.gre.ac.uk/15096/

Stenström, M.-L., \& Virolainen, M. (2014a). The current state and challenges of vocational education and training in Finland. Roskilde: Nord-VET. Retrieved from http://nord-vet.dk/indhold/uploads/ report1b_fi.pdf

Stenström, M.-L., \& Virolainen, M. (2014b). The history of Finnish vocational education and training. Roskilde: Nord-VET. Retrieved from http://nord-vet.dk/indhold/uploads/report1a_fi.pdf

Streeck, W. (1989). Skills and the limits of neo-liberalism: The enterprise of the future as a place of learning. Work, Employment and Society, 3(1), 89-104. https://doi.org/10.1177/0950017089003001006

UN Economic and Social Council. (2005). Article 6 of the International Covenant on Economic, Social and Cultural Rights. Retrieved from http://docstore.ohchr.org/SelfServices/FilesHandler.ash $\mathrm{x}$ ?enc=4slQ6QSmlBEDzFEovLCuW1a0Szab0oXTdImnsJZZVQfUKxXVisd7Dae\%2FCu\%2B13J2 5Nha7l9NlwYZ\%2FTmK57O\%2FSr7TB2hbCAidyVu5x7XcqjNXn44LZ52C\%2BIkX8AGQrVyIc 
Ünlühisarcikli, Ö. (2001). Training on the job in Istanbul: A study of skills acquisition in carpentry and car-repair workshops. International Review of Education, 47(5), 443-458. https://doi.org/10.1023/A:1012220530173

Valiente, O., \& Scandurra, R. (2017). Challenges to the implementation of dual apprenticeships in OECD countries: A literature review. In M. Pilz (Ed.), Vocational education and training in times of economic crisis: Lessons from around the world (pp. 41-57). Cham, Switzerland: Springer. https://doi.org/10.1007/978-3-319-47856-2_3

Williams, J., Foley, B., \& Newton, B. (2013). Report for unionlearn and the national apprenticeship service: Research into under-representation, by gender and ethnicity, in apprenticeships. Report No. 503. Brighton: Institute for Employment Studies. Retrieved from http://www.employment-studies. co.uk/system/files/resources/files/503.pdf

Wolter, A., \& Kerst, C. (2015). The 'academization' of the German qualification system: Recent developments in the relationships between vocational training and higher education in Germany. Research in Comparative and International Education, 10(4), 510-524.

Wolter, S. C., \& Ryan, P. (2011). Apprenticeship. In E. A. Hanushek, S. Machin, \& L. Woessmann (Eds.), Handbook of the Economics of Education (pp. 521-576). Volume 3. Amsterdam, The Netherlands: North-Holland.

Yahaya, N., Rasul, M. S., \& Yasin, R. M. (2016). Social skills and social values in Malaysian dual training system apprenticeship. In A. G. Abdullah, T. Aryanti, A. B. D. Nandiyanto, V. Adriany, \& A. Aripin (Eds.), The Proceedings of 2015 International Conference on Innovation in Engineering and Vocational Education (pp. 170-175). Bandung, Indonesia: Universitas Pendidikan Indonesia. https://doi.org/10.2991/icieve-15.2016.36

Young, M. (1995). Forum. Beyond apprenticeship and schooling: Issues for the future of education and training in Africa. International Review of Education, 41(1-2), 137-138. https://doi.org/10.1007/ BF01099296 


\section{Biographical Notes}

Dr Maia Chankseliani is Associate Professor of Comparative and International Education at the University of Oxford. Maia Chankseliani's research on tertiary education - higher education, university-based research, and VET/apprenticeships - focuses on the understanding of the societal, institutional, and policy forces that shape tertiary education and the potential of tertiary education and research for transforming societies.

Aizuddin Mohamed Anuar is a DPhil in Education student at the University of Oxford. Within the field of comparative and international education, his research interests include education and inter/national development, postcolonialism, rural education and cultural studies in science education.

\section{Acknowledgments}

This work was supported by Qatar Foundation. We are grateful to Peter Brookes for his comments on an early version of this article. 